\title{
ASSESSMENT OF HEALTH CADRES' KNOWLEDGE ON DANGER SIGNS OF PREGNANCY
}

\author{
Restuning Widiasih, Ida Maryati, Yanti Hermayanti, Tetti Solehati \\ Department of Maternity Nursing, Nursing Faculty, Universitas Padjadjaran \\ Correspondence: restuning.widiasih@unpad.ac.id
}

\begin{abstract}
Maternal mortality rates (MMR) in Indonesia have not reached the target of Sustainable Development Goals (SDGs). The Indonesian government has established a Delivery Planning and Complication Prevention program (P4K) that focuses on community empowerment including health cadres. Health cadres have a significant role in preventing of maternal mortality in the maternal periods (pregnancy, childbirth, and postpartum), including early detection of danger signs of pregnancy. However, there is limited research in Indonesia that examines cadre's knowledge about the danger signs of pregnancy in detail. This study aimed to assess cadres' knowledge of danger signs in the maternal period especially in pregnancy. This research is a quantitative descriptive study. The study was conducted in Tempuran sub-district, Karawang regency, West Java. 48 cadres were involved in this study. Respondents filled in questionnaires about the danger signs of pregnancy. The results showed that the majority of cadres understood danger signs in pregnancy. Premature rupture of membranes $(91.6 \%)$ and convulsions (91.6\%) were danger signs that best known by cadres. While the signs of vaginal discharge $(8 \%)$, heartburn $(8 \%)$, and prolonged labor $(4 \%)$ were little known by cadres as part of danger signs of pregnancy. The level of cadre knowledge about danger signs of pregnancy is varied. This research is the baselines information that may useful for program developments in relation to increase cadre capacity in preventing maternal mortality in the maternal periods.
\end{abstract}

Keywords: Cadres, knowledge, danger signs of pregnancy

\section{INTRODUCTION}

Pregnancy is a part of women's normal development that requires physical and psychological adaptations. The adaptation process is sometimes accompanied by complications that affect maternal mortality. The maternal mortality is death during pregnancy up to 42 days after giving birth due to pregnancy and its interventions, but not because of an accident (World Health Organization, 2018). According to data from the World Health Organization (2018) 830 pregnant and giving birth women die every day, 99\% come from developing countries, women from rural areas, and poor women . One of the target SDGs is to reduce MMR to 70 / 100,000 live births in 2030. Indonesia is a developing country with MMR that is still above the SDGs target 
which is $305 / 100,000$ live births (Putro \& Maisya, 2018). Dealing with the high MMR is the concern of the Indonesian government in the health development program and strategy, including identifying causes and developing programs to overcome the MMR problems.

The causes of maternal deaths in Indonesia are categorised into several factors including socioeconomics (culture, education, economic, and facilities), delays models (delay in decision, reach health care, and receive care), and four too (too young, too old, too frequent, too many) (Widiasih, Ermiati, \& Setyawati, 2018). According to WHO, the causes of maternal mortality are divided into two including direct causes and indirect causes (indirect obstructive deaths). Direct causes are direct maternal death caused by obstetric complications during pregnancy, childbirth and post-partum such as bleeding, texomia, and infection. The indirect cause is maternal death caused by a disease that is not obstetric complications that occur or increase due to pregnancy, childbirth and post-partum (Nurmawati, 2017). Maternal mortality in Indonesia is dominated by three main causes, including bleeding, preeclampsia, and infection. (Ministry of Health, 2013; Yanti, 2016).

In reducing the Maternal Mortality Rate (MMR) in Indonesia, the Ministry of Health has established a Delivery Planning and Complication Prevention program (P4K). The implementation of this program in villages was registering pregnant women in each village shown, putting stickers in every house where there were pregnant women, pregnant women who have been found to receive care for pregnancy care, delivery by health workers, villages organize the readiness of the prospective blood donors or there are blood donors, and villages have a village 
transportation that can be used at any time to refer patients (an ambulance car) (Dharminto, 2013). The P4K program focuses on community empowerment by involving various community elements to prevent maternal mortality. Community support such as family, cadres, community leaders and religious leaders is important to support maternal health (Kementrian Kesehatan R1, 2014; Kusumastuti, 2015). Cadres themselves are local communities who are selected, work voluntarily (Kusumastuti, 2015).

These health cadres have a very important role in the maternal health, such as assisting midwives in recording the number of pregnant women in their neighbourhood, providing counseling related to maternal health (danger signs of pregnancy, childbirth and postpartum), assisting midwives in facilitating families to agree on the contents of the intended stickers post giving birth, together with cadres, Toma discussed the problem of prospective blood donors, transportation, and financing to help with emergency during pregnancy, maternity and after childbirth, encouraging husbands to assist during pregnancy, childbirth, and postpartum examinations, and advocating for giving Exclusive breastfeeding for infants up to 6 months of age (Kementrian Kesehatan RI, 2014; Dharmawan, 2013).

The research conducted by Pangestu (2017) found that cadres have 4 important roles, first is $\mathrm{MCH}$ surveillance, reduction in maternal mortality, infant mortality, and children mortality, increasing coverage of pregnancy check-up, early detection of pregnancy with abnormalities, and monitoring of pregnancy, and the role of increasing POSYANDU participation and early detection of children's growth issues. From the 4 important roles of cadres, there are still many problems identified, such as 
cadres who are not active in filling out foster cadre books because they cannot read and write, then in the POSYANDU activity there are cadres who are not active, in the home visit many cadres do not visit the mother pregnant, and in early detection of toddler development, many cadres do not have the knowledge of developing toddlers. From the previous research, cadres are expected to have a broad role to improve maternal health and prevent maternal deaths, but cadres faces a lack of knowledge issues

Health promotion and prevention of women during pregnancy is important for all parties, including health cadres. The health cadres were one of the closest people to pregnant women in Indonesia who help to facilitate pregnant women's health, especially pregnant women in their neighborhood. Adequate knowledge of the pregnancy conditions, especially the danger signs of pregnancy, are important to be understood by cadres. However, there is little information about cadre knowledge of the danger signs of pregnancy in detail as mentioned in the pregnancy guidelines book. This study aimed to assess cadres' knowledge of the danger signs of pregnancy from several aspects including infection, bleeding, preeclampsia, nutrition, and foetal conditions.

\section{METHODS}

This study was a quantitative descriptive study. The population in this study were health cadres in Tempuran District, Karawang Regency, West Java. This subdistrict is a region that has a collaboration with Padjadjaran University for community services 
programs, including the Faculty of Nursing which conducts training for health cadres. The sample in this study was chosen by non-probability sampling, namely consecutive sampling technique. Samples were 48 health cadres from 9 villages who attended a health cadre training in the sub-district office. Cadres who were involved in the training were chosen by the local leader in each village. The research instrument was a questionnaire. The questionnaire was developed based on maternal danger signs material in the guidebook for pregnant women published by the ministry of health and is owned by all pregnant women. The questionnaire consists of 3 parts, the first part was questions related to the respondents' sociodemographics including age, sex, marital status, job, education, and history of training as a cadre. The second part was pictures of danger signs on the maternal periods, respondents were asked to answer the question " what is the health risk of pregnancy, childbirth, and postpartum based on the image?" There were 12 images. The third part was a question "what impact might occur due to the risk condition on the maternal periods?". Data were collected on October 2018 and analyzed using frequency distribution, and respondents' answers were categorized into knowing and not knowing.

\section{RESULT}

The characteristics of respondents described the history of respondents' sociodemographic including age, gender, marital status, tribe, occupation, education, and the history of cadre's training 
Table 1. Characteristic of respondents

\begin{tabular}{|c|c|c|}
\hline \multicolumn{3}{|l|}{ Characteristics } \\
\hline Ages & & \\
\hline$-\quad 20-29$ & 9 & 18.75 \\
\hline$-\quad 30-39$ & 17 & 35.41 \\
\hline$-\quad 40-49$ & 13 & 27.08 \\
\hline$-\quad 50-59$ & 4 & 8.33 \\
\hline \multicolumn{3}{|l|}{ Sex } \\
\hline - female & 47 & 97.9 \\
\hline - male & 1 & 2.1 \\
\hline \multicolumn{3}{|l|}{ Marital status } \\
\hline - $\quad$ Married & 46 & 95.8 \\
\hline - Divorce & 2 & 4.2 \\
\hline \multicolumn{3}{|l|}{ Tribes } \\
\hline - $\quad$ Sundanese & 42 & 87.5 \\
\hline - Javanese & 5 & 10.4 \\
\hline - Batak & 1 & 2.1 \\
\hline \multicolumn{3}{|l|}{ Occupation } \\
\hline - Unemployment & 20 & 41.7 \\
\hline - Farmer & 3 & 6.2 \\
\hline - Government officer & 3 & 6.2 \\
\hline - Private company & 1 & 2.1 \\
\hline - Self-employed & 11 & 22.9 \\
\hline - Others & 10 & 20.8 \\
\hline \multicolumn{3}{|l|}{ Education } \\
\hline - No School & 1 & 2.1 \\
\hline - Elementary School & 12 & 25.0 \\
\hline - Junior high school & 16 & 33.3 \\
\hline - Senior high school & 15 & 31.2 \\
\hline - University & 4 & 8.3 \\
\hline \multicolumn{3}{|l|}{ Training programs } \\
\hline - Attended & 6 & 12.5 \\
\hline - Unattended & 42 & 87.5 \\
\hline
\end{tabular}

Table 1 shows that the majority of cadres aged 30-39 years. The cadres were married (95.8\%) and two divorced. The average Sundanese cadre was in accordance with the research location in West Java, so in terms of language and culture, there may be no problems in delivering information from cadres to the community. The highest level of formal education was the university. The majority of cadres had not experienced in attending training to improve cadres' capability ( $87.5 \%$ ). 
Restuning Widiasih : Assessment Of Health Cadres’ Knowledge on Danger Signs of Pregnancy

Table 2. Health cadre's knowledge of danger signs in the maternal period

\begin{tabular}{|c|c|c|c|c|c|c|}
\hline \multirow[t]{2}{*}{ No } & \multirow[t]{2}{*}{ Danger signs } & \multirow[t]{2}{*}{ Components } & \multicolumn{2}{|c|}{ Knowing } & \multicolumn{2}{|c|}{ Not Knowing } \\
\hline & & & $\mathrm{f}$ & $\%$ & $\mathrm{f}$ & $\%$ \\
\hline \multirow[t]{3}{*}{1.} & \multirow[t]{3}{*}{ Infection } & Discharges & 8 & 16.7 & 40 & 83.3 \\
\hline & & $\begin{array}{l}\text { Hyperthermia more than } 3 \\
\text { days }\end{array}$ & 36 & 75 & 12 & 25 \\
\hline & & Premature rupture membranes & 44 & 91.6 & 4 & 8.4 \\
\hline 2 & Bleeding & Bleeding & 36 & 75 & 12 & 25 \\
\hline \multirow[t]{3}{*}{3} & \multirow[t]{3}{*}{ Preeclampsia } & A headache & 36 & 75 & 12 & 25 \\
\hline & & Heartburn & 8 & 16.7 & 40 & 83.3 \\
\hline & & Convulsions & 11 & 91.6 & 4 & 8.4 \\
\hline 4 & Dehydration and Nutrition & Hyperemesis & 36 & 75 & 12 & 25 \\
\hline \multirow[t]{2}{*}{5} & \multirow[b]{2}{*}{ Breathing issues } & Asphyxiate & 32 & 66.6 & 16 & 33.4 \\
\hline & & Coughing more than 2 weeks & 32 & 66.6 & 16 & 33.4 \\
\hline \multirow[t]{2}{*}{2.} & \multirow{2}{*}{$\begin{array}{l}\text { Conditions that threatening } \\
\text { fetal }\end{array}$} & The fetus doesn't move & 36 & 75 & 12 & 25 \\
\hline & & Prolong labor & 4 & 8.4 & 11 & 91.6 \\
\hline
\end{tabular}

Table 3 revealed that the majority of cadres had understood related to danger signs in the maternal period. Premature rupture of membranes (91.6\%) and convulsions $(91.6 \%)$ were danger signs that best known by cadres. While the signs of vaginal discharge, heartburn, and long labor are little known by cadres as a danger sign in pregnancy.

\section{DISCUSSION}

The results of the study showed that cadres knew the danger signs of pregnancy well. Danger signs are grouped into infections, bleeding, high blood pressure, dehydration and nutrition, breathing, and danger signs related to conditions that threatening the fetal. However, there were some danger signs that were not understood by cadres, namely vaginal discharge, heartburn, and prolonged labor. The results of this study are different from previous studies which found that cadre knowledge about danger 
signs in pregnancy was moderate level (Palupi, 2012). The study did not explain in detail of the scope of knowledge being studied, the published results only reported the cadres' level of knowledge in the three categories of good, moderate, and poor. While this study describes in detail the scope of knowledge related to danger signs in pregnancy that are known by cadres. This research provides a new insight related to cadres' knowledge of danger signs in the maternal periods in details. This specific information would be useful as baselines data for developing cadre capacity building programs because based on the sociodemographic assessment result most cadres have never attended cadre training. Cadre training is important, as the results of research conducted by Kusumawardini (2018), activities that would increase cadres' knowledge, including a capacity training carried out by the PHC. The PHC request to each local leader in the village to send cadres from each post to attend the cadre training programs.

Knowledge possessed by cadres illustrates that cadres would be able to have a significant role in supporting a program to reduce maternal mortality. The role of cadres in the prevention of maternal and infant mortality includes early detection of the health of pregnant women, early detection of health problems for infants and toddlers, monitoring of maternal and child health in their residential areas, and reporting to village midwives when mothers, infants, and toddlers have health problems (Pangestu, 2017). Research conducted by Sakinah (2015) found that cadres played an important role in increasing the number of ANC visits. ANC examination for pregnant women aims to detect abnormalities that may arise during pregnancy (Usman, 2018). Sakinah explained that an effective way to increase the number of 
ANC visits of pregnant women was counseling, motivation support, and assistance during ANC. One of the factors that influence the success of the cadre's role was the community's trust especially pregnant women (Sakinah, 2015). Increasing the role of cadres in the community, especially in helping women in the maternal period is one form of community empowerment. Empowerment of Cadres was an activity carried out to encourage the healthy behavior of individuals or communities (Sakinah, 2015).

The results of the study showed that there were cadres who did not aware of several danger signs of pregnancy. The poor cadres' knowledge about health was also found in the study (Chakraborty, Murphy, Paudel, \& Sharma, 2015), although the study examined cadre knowledge about the family planning especially IUD program, but could support a description that improving health cadre's knowledge is needed. The research conducted by Kusumawardini (2018) found factors that influence the performance of cadres in increasing the participation of pregnant women in participating in the ANC program, including cadre living environments, cadre experiences, referral to health information by the community, and cadre colleagues with have the same vision and mission. Various cadres capacity building has been carried out such as increasing the capacity of cadres in implementing toddler growth monitoring at POSYANDU (Rubai, Hasibuan, Dani, and Putro, 2015), increasing cadres social support in breast cancer patients (Witdiawati, Sukmawati, Mamuroh, 2018 ), and capacity building of Posyandu cadres in identifying problems and addressing them (Khuluqo, 2015). No capacity building has been focused on the danger signs in the maternal period. The results of this study can be preliminary data 
Restuning Widiasih : Assessment Of Health Cadres’ Knowledge on Danger Signs of Pregnancy

relating to the need to increase the capacity of cadres on topics that aim to support programs for reducing MMR, including danger signs in the maternal period.

\section{CONCLUSION}

The cadre's level of knowledge about danger signs during the maternal period is good, however, there are cadres who do not know yet about danger signs in the maternal periods. This research is the initial data that describes in detail the components of maternal danger signs that are known and unknown by cadres. Cadre capacity building activities are needed on topics that aim to support the program to reduce $M M R$, including danger signs in the maternal period because there are a few cadres capacity building programs that focus on danger signs of pregnancy, childbirth, and post-partum

\section{REFERENCES}

Antoni, Agustika. (2018). Gambaran tingkat pengetahuan ibu hamil tentang pencegahan dan penatalaksanaan resiko tinggi kehamilan di Kelurahan Tabing wilayah kerja Puskesmas Lubuk Buaya Padang. MENARAilmu, 12(3), $11-18$

Chasanah, Siti Uswatun. (2015). Peran petugas kesehatan masyarakat dalam upaya penurunan angka kematian ibu pasca MDG's 2015. Jurnal kesehatan masyarakat Andalas, 73-79 
Restuning Widiasih : Assessment Of Health Cadres’ Knowledge on Danger Signs of Pregnancy

Dewi, Ratna. (2017). Efek pemberian ekstrak buah nanas muda dan tua (Anana. C. L.Merr) terhadap kejadian abortus pada mencit (Mus Musculus). Jurnal Bahana Kesehatan Masyarakat, 1(1), 1-7.

Dharmawan, Y., Dharminto S., dkk. (2013). Refresing kader kesehatan dalam program perencanaan persalinan dan pencengahan komplikasi (P4K) Kecamatan Mranggen Kabupaten Demak. Majalah INFO, 15(2), 45-52 Kementrian Kesehatan RI. (2014). Infodatin situasi kesehatan ibu.

Kolifah. (2017). Pengaruh pelaksanaan pendampingan kader terhadap kunjungan Antenatal Care (ANC) ibu hamil resiko tinggi di Megaluh Jombang. Jurnal ilmiah kesehatan, 10(1), 16-23.

Kusumastuti., Eka Novyriana., Dwi Utami. (2015). Gambaran peran kader dalam pelaksanaan program perencanaan persalinan dan pencegahan komplikasi (P4K) di wilayah kerja Puskesmas Padureso Kabupaten Kebumen. Jurnal ilmiah kesehatan keperawatan, 11(3), 105-115

Kusumawardini, Ade Sintya., Pudji Muljono. (2018). Hubungan sikap dan motivasi kerja dengan kinerja kader posyandu, kasus: Desa Cooer dan Desa Kutuwetam Kecamatan Jetis, Kabupaten Ponorogo. Jurnal sains komunikasi dan pengembangan masyarakat (JSKPM), 2(2), 223-238.

Nurmawati. (2017). Faktor-faktor yang berhubungan dengan kehamilan resiko tinggi di Puskesmas Cibatu Kabupaten Bekasi Provinsi Jawa Barat tahun 2017. Jurnal ilmu dan budaya, 40(57), 6669-6684

Nurrizka, Rahma Hida., Tri Yunis MW. (2018). Disparitas kematian maternal di Indonesia: Studi ekologi dengan analisa spasial. Jurnal MKMI, 14(2), 119-127 
Restuning Widiasih : Assessment Of Health Cadres’ Knowledge on Danger Signs of Pregnancy

Pangestu, Ninil Dwi., Hermanu Joebagio., Setyo Sri Rahardjo. (2017). The role of community health workers in maternal and child health surveillance to optimize maternal and child health in Pasuruan District, East Java. Journal of health policy and management, 2(2), 128-136.

Putro, G., \& Maisya, I. B. (2018). Determinan Sosial dalam Kematian Maternal di RSUD dr. Abdoer Rahem Kabupaten Situbondo, Global Medical and Health Communication, 6(1), 74-82.

Rachmawati, Ayu Indah., Ratna DP., Eka Cania. (2017). Faktor-faktor yang mempengaruhi kunjungan Antenatal Care (ANC) ibu hamil. Majority, 7(1), $72-76$

Sakinah, Vika., Arulita Ika Fibriana. (2015). Upaya peningkatan pengetahuan, sikap dan kunjungan Antenatal care (ANC) Ibu hamil melalui pemberdayaan kader ANC. Unnes journal of public health, 4(1), 54-60.

Susanti., Titin Kartiyani. (2016). Efektifitas pelatuhan kader posyandu tentang deteksi dini tanda bahaya kehamilan dengan metode indeks card match. Jurnal kesehatan Al-Irsyad (JKA), 9(2), 1-7.

Wahyuni, Sri., Endang Wahyuningsih. (2016). Efektifitas penyuluhan kesehatan tentang program perencanaan persalinan dan pencegahan komplikasi terhadap peningkatan pengetahuan dan P4K pada ibu hamil di wilayah Puskesmas Karangnongko Klaten. MOTORIK, 11(23), 64-76

Widiasih, R., Ermiati, \& Setyawati, A. (2018). Women's Health Behaviour in The Perinatal Period. Journal of Nursing Care, 1(1). doi: https://doi.org/10.24198/jnc.v1i1.15759 
Restuning Widiasih : Assessment Of Health Cadres’ Knowledge on Danger Signs of Pregnancy

Widodo, Yekti., Nurmala KP., Djoko Susanto. (2017). Pengaruh faktor sosial ekonomi dan budaya terhadap perilaku persalinan di perdesaan daerah angka kematian ibu rendah dan tinggi. Jurnal kesehatan reproduksi, 8(1), 77-88

World Health Organization. (2018). Maternal Mortality. Retrieved from https://www.who.int/news-room/fact-sheets/detail/maternal-mortality

Zakaria, Fatma. (2015). Hubungan pengetahuan dengan sikap ibu hamil tentang tanda-tanda bahaya selama kehamilan di Puskesmas Bahu Kecamatan Malalayang kota Manado. Prosiding Seminar Nasional, 250-256. 